Research Article

\title{
Anti-inflammatory potential of african leaf water extract
}

\author{
Lusi Agus Setiani*, Zaldy Rusli \\ Department of Pharmacy, Faculty of Math and Science, Pakuan University, Bogor, Indonesia
}

\section{Article history:}

Submitted 15 September 2020

Accepted 16 October 2020

Published 23 December 2020

Keywords:

African leaf

Flavonoid

Inflammation

In vitro

In vivo

*Corresponding author:

E-mail: lusi.setiani@unpak.ac.id

\begin{abstract}
Inflammation is the immune system's main response to infection and irritation. African leaf (Gymnanthemum amygdalinum) is one of the medicinal plants that can be used as anti-inflammatory because of the presence of flavonoid compounds. Flavonoid compounds have an anti-inflammatory effect that can regulate arachidonic acid metabolism by inhibiting cyclooxygenase (COX) and lipooksigenase activities. This study aims to obtain scientific information and the potential of African leaf extract as an anti-inflammatory in vitro and in vivo test. In this study, in vitro and in vivo anti-inflammatory activity tests were carried out. The in vitro anti-inflammatory activity was evaluated by the ability of African leaf extracts to prevent protein denaturation and in vivo anti-inflammatory activity by observing the reduction of edema in the soles of rats induced by carrageenan by giving three levels of doses of African leaf extract. The results showed that the African leaf extract at a concentration of $8273.91 \mathrm{mg} \mathrm{L}^{-1}$ was able to inhibit $50 \%$ denatured protein ( $\mathrm{IC}_{50}$ ), while in the in vivo test African leaf had the potential as an anti-inflammatory with the most effective percentage of inhibition at a dose of $200 \mathrm{mg} \mathrm{kg}^{-1}$ which is $85.20 \%$. African leaf have the potential of approximately 2 times greater than the positive control of diclofenac sodium which is $45.70 \%$.
\end{abstract}

\section{Introduction}

Inflammation is one of the main responses of the immune system to injury, infection and cell damage characterized by heat, redness, pain, swelling and impaired physiological function. The drugs commonly used to control inflammation are non-steroidal anti-inflammatory drugs, which have several side effects, especially gastric irritation (Drini, 2017).

One of the medicinal plants that can be used as anti-inflammatory is African leaf (Gymnanthemum amygdalinum) (Georgewill and Georgewill, 2010). African leaf, commonly known as bitter leaf, is a shrub that grows up to
3 meters high in the African tropics and other parts of Africa, particularly, Nigeria, Cameroon and Zimbabwe. It is reputed to have several health benefits (Farombi et al., 2011) African contain vernoniosides A1, A2, A3, B1, B2, B3, sesquiterpenes, lactones, vernolides, vernodalol, vernolepin, vernodalin, vernomygdin, hydroxylvernolide, tannins, luteolin, and xanthan (Ijeh \& Ejeh 2011).

The infusion method can only search for polar substances where one of these compounds is a flavonoid and the anti-inflammatory activity of various plants is thought to be derived from flavonoids (Ramadhani, 2013). 
The mechanism of flavonoids is to inhibit lipid peroxidation, so that will reduce the adhesion of inflammatory cells to the endothelium and generally reduce the inflammatory response (Nijveldt et al., 2012).

The in vitro anti-inflammatory activity was evaluated by the ability of African leaf extracts to prevent protein denaturation. In vivo antiinflammatory activity was carried out by observing the reduction of edema in the soles of the white rats induced by carrageenan with three levels of doses of African leaf extract. This study aims to obtain scientific information and the potential of African leaf extract anti-inflammatory activity.

\section{Materials and Methods Materials and apparatus}

The tools used in this study include rat cages, pletismometer, analytical scales, animal scales, glassware, Uv-Vis spectrophotometer and a water bath. The ingredients used are Bitter leaf $2 \%$ of carrageenan, $0.5 \%$ of $\mathrm{CMC}-\mathrm{Na}$, aquadestilata, $50 \mathrm{mg}$ diclofenac sodium tablets, sodium potassium tartrate, copper sulfate, $\mathrm{NaOH}, \mathrm{NaCl}, \mathrm{KCl}, \mathrm{Na}_{2} \mathrm{HPO}_{4}, \mathrm{KH}_{2} \mathrm{PO}_{4}$, Bovine Albumin Serum and methanol. The test animals used in the study were 30 male white rats Sprague-Dawley strain aged 2-3 months with a weight of \pm 200 gram.

\section{Time and site}

This research was conducted from May to July 2020 at the Pharmacy Laboratory, Mathematics and Natural Science Faculty, University of Pakuan, Bogor and the Tropical Biofarmaka Study Center, Research and Community Services Program, Bogor Agricultural Institute.

\section{Methods of experiment}

African leaf collection (Gymnanthemum amygdalinum)

African leaf are obtained from Cariu Village, Bogor Regency. Plant determination is carried out at the Plant Conservation Center of the Indonesian Institute of Sciences (LIPI). Cibinong, Bogor. Air-drying, dry bitter leaf is sorted, grinded and sieved with a 30 mesh sieve. The water content and ash content were determined (Hanani, 2015).
Preparation of african leaf water extract

An extract of African leaf is made by weigh $200 \mathrm{~g}$ of the powder of African leaf and added 2 $\mathrm{L}$ of aquadest in the infusion pan. Heated on a water bath for 15 minutes starting from the temperature reaching $90^{\circ} \mathrm{C}$ while stirring occasionally. The water extract is filtered using filter paper, then adding hot water through the dregs up to a volume of $2 \mathrm{~L}$. Then performed a phytochemical test (alkaloid, flavonoid, saponin, and tannin) (Hanani, 2015).

\section{In vitro anti-inflammatory activity test}

The in vitro anti-inflammatory activity was evaluated by the ability of African leaf extracts to prevent protein denaturation (Hildebrandt et al., 2008).

\section{Preparation of protein reagents}

$2 \mathrm{~g}$ of sodium potassium tartrate, $1 \mathrm{~g}$ of copper sulfate are weighed and dissolved in $90 \mathrm{~mL}$ of aquabides, then $10 \mathrm{~mL}$ of $1 \mathrm{~N} \mathrm{NaOH}$ are added (Hildebrandt et al., 2008).

\section{Preparation of phosphate buffer $\mathrm{pH} 7.4$}

In $800 \mathrm{~mL}$ of aquabidest, $8 \mathrm{~g}$ of $\mathrm{NaCl}, 200 \mathrm{mg}$ of $\mathrm{KCl}, 1.44 \mathrm{~g}$ of $\mathrm{Na}_{2} \mathrm{HPO}_{4}$ and $245 \mathrm{mg}$ of $\mathrm{KH}_{2} \mathrm{PO}_{4}$ are dissolved. Measured the $\mathrm{pH}$ with adjusting using Phosphoric Acid or $\mathrm{NaOH}$ (Bertholf, 2014).

\section{Preparation of 0.6\% BSA solution}

The $0.6 \%$ BSA solution was prepared by weighing $0.6 \mathrm{~g}$ of BSA and then dissolving it in $100 \mathrm{~mL}$ of aquabidest.

\section{Preparation of test solutions}

The test solution consisted of 2, namely diclofenac sodium solution and African leaf extract solution. The diclofenac sodium test solution was prepared by weighing $500 \mathrm{mg}$ of standard diclofenac sodium, dissolving $10 \mathrm{~mL}$ of methanol, then adding up to $100 \mathrm{~mL}$ using aquabidest, so that the main solution of diclofenac sodium with a concentration of $5000 \mathrm{mg}$ $\mathrm{L}^{-1}$ was obtained. Extract solution of African leaf is made by weighing $12 \mathrm{~g}$ of powder of Bitter leaf, then boiling it in $100 \mathrm{~mL}$ of aquabidest at $90{ }^{\circ} \mathrm{C}$ for 15 minutes. After cooling the extract was filtered and added to $100 \mathrm{~mL}$ using 
aquabidest, so that the extract solution was obtained with a concentration of $120000 \mathrm{mg} \mathrm{L}^{-1}$ (Hildebrandt et al., 2008).

\section{Analysis}

Positive control solutions were prepared by mixing $1.5 \mathrm{~mL}$ of $0.6 \%$ BSA solution, $1.5 \mathrm{~mL}$ of phosphate buffer solution pH 6.4 and $6 \mathrm{~mL}$ of protein reagent solution. The absorption of the mixture was directly measured using a spectrophotometer at a wavelength of $540 \mathrm{~nm}$ (without treatment) (Bertholf, 2014; Hildebrandt et al., 2008).

Negative control solution was prepared by mixing $1.5 \mathrm{~mL}$ of $0.6 \%$ BSA solution, $1.5 \mathrm{~mL}$ of phosphate buffer solution $\mathrm{pH} 6.4$ and $6 \mathrm{~mL}$ of protein reagent solution. The mixture was then heated at $37{ }^{\circ} \mathrm{C}$ for 30 minutes, then heated at $70{ }^{\circ} \mathrm{C}$ for 10 minutes. After cooling, the absorption of each solution was measured using a spectrophotometer at a wavelength of $540 \mathrm{~nm}$ (with treatment) (Bertholf, 2014; Hildebrandt et al., 2008).

The difference between negative and positive controls is that in the negative control, heating is carried out while in the positive control it is not, this is to illustrate the occurrence of protein denaturation due to heating.

The test solution for diclofenac sodium was made into a series of test solutions with $0.06 \mathrm{pi}$ pettes; $0.12 ; 0.36 ; 0.6$ and $0.12 \mathrm{~mL}$ of the 5,000 $\mathrm{mg} \mathrm{L}^{-1}$ test solution into 5 test tubes, then add up to $1.5 \mathrm{~mL}$ of each tube using a phosphate buffer. To each tube, $1.5 \mathrm{~mL}$ of $0.6 \%$ BSA solution was added. This mixture was then heated at $37^{\circ} \mathrm{C}$ for 30 minutes, then heated at $70^{\circ} \mathrm{C}$ for 10 minutes. After cooling, the absorption of each solution was measured using a spectrophotometer at a wavelength of $540 \mathrm{~nm}$ (Bertholf, 2014).

Extract solution of African leaf is made into a series of test solutions with 50 pipettes; 100; 150; 200 and $250 \mu \mathrm{L}$ of $120,000 \mathrm{mg} \mathrm{L}^{-1}$ mother liquor into 5 test tubes, then add up to $1.5 \mathrm{~mL}$ of each tube using phosphate buffer (Bertholf, 2014; Hildebrandt et al., 2008).

To each tube, $1.5 \mathrm{~mL}$ of $0.6 \%$ BSA solution was added. This mixture was then heated at 37 ${ }^{\circ} \mathrm{C}$ for 30 minutes, then heated at $70{ }^{\circ} \mathrm{C}$ for 10 minutes. After cooling, the absorption of each solution was measured using a spectrophotometer at a wavelength of $540 \mathrm{~nm}$. Protein denaturation inhibitory activity is measured using the formula (Bertholf, 2014; Hildebrandt et al., 2008; Quasie, 2016) :

Inhibition Ability

$(I C)=\frac{A_{\text {sample }}-A_{\text {negative control }}}{A_{\text {positive control }}-A_{\text {negative control }}} \times 100 \%$

Explanation :

Asample : diclofenac sodium solution and sample absorption

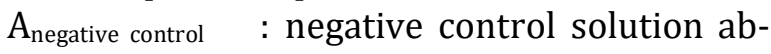
sorption

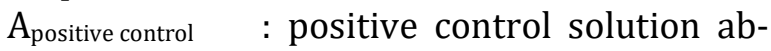
sorption

Furthermore, a graph of the relationship between concentration (x-axis) and drag (yaxis) is drawn, then the linear regression equation is determined. The linear regression equation is used to calculate the concentration that can inhibit the denaturation of $50 \%$ protein $\left(\mathrm{IC}_{50}\right)$.

\section{In vivo anti-inflammatory activity test}

In vivo anti-inflammatory testing in this study was by subplantar injection of carrageenan solution, then measuring the volume of edema on the soles of the rats' feet was measured using a pletismometer. The anti-inflammatory activity was shown by the ability of the test material to reduce edema caused by carrageenan induction on the soles of the feet of the test animals (Mishra et al., 2011).

\section{Ethics review}

This research has been approved by the Animal Ethics Commission Team, Faculty of Mathematics and Natural Sciences, Pakuan University with the Ethics Committee Decree No. 102/KEPHP-UNPAK/05-2020.

\section{Research design}

Rats were randomly divided into five treatment groups, each group consisting of 6 rats. Group I as a negative control was given CMC-Na solution, group II as a positive control was given diclofenac sodium, groups III, IV, and V 
were given water extract of African leaf with three dose ratings, namely $100 \mathrm{mg} \mathrm{kg}^{-1}, 150 \mathrm{mg}$ $\mathrm{kg}^{-1}, 200 \mathrm{mg} \mathrm{kg}^{-1}$.

\section{Preparation the dosage}

The extract dosage used in this study was $100 \mathrm{mg} \mathrm{kg}^{-1}$ for dose I, $150 \mathrm{mg} \mathrm{kg}^{-1}$ for dose II, $200 \mathrm{mg} \mathrm{kg}^{-1}$ for dose III, $5.3 \mathrm{mg} \mathrm{kg}^{-1}$ diclofenac sodium as positive control.

\section{Preparation of diclofenac sodium suspension}

Diclofenac sodium tablet $50 \mathrm{mg}$ finely crushed, then sieved and taken as much as 4.5 mg. After that this diclofenac sodium powder was suspended in $10 \mathrm{~mL}$ of $0.5 \% \mathrm{CMC}-\mathrm{Na}$ until it was homogeneous. The dosage of diclofenac sodium is $5.3 \mathrm{mg} \mathrm{kg}^{-1}$.

\section{Preparation of extract suspensions}

The water extract of African leaves was weighed as much as 20.30 and $40 \mathrm{mg}$. Each was crushed with the addition of $0.5 \%$ CMC-Na suspension until homogeneous, put into a $10 \mathrm{~mL}$ volumetric flask, stirred to the mark with $0.5 \%$ CMC-Na suspension (Mishra et al., 2011).

\section{Inflammation inductor preparation}

Carrageenan is weighed as much as $200 \mathrm{mg}$, then dissolved in $10 \mathrm{~mL}$ of physiological $\mathrm{NaCl}$ solution and stirred to obtain a $2 \%$ concentration of carrageenan suspension (Mishra et al., 2011).

\section{Inflammation testing}

The test was started by fasting the mice for 18 hours while still giving them drinking. Rats were grouped into 6 treatment groups. The rat's left leg was inserted into a plestimometer containing liquid mercury until the liquid rose to the upper boundary line, the number was recorded on the instrument as the initial volume (Vo), namely the volume of the leg before being given the drug and induced with a carrageenan solution (Mishra et al., 2011).

Each rats were given a suspension of the test material orally according to its group. 15 minutes later, each of the rats' feet was injected subplantar with $0.2 \mathrm{~mL}$ of $2 \%$ carrageenan solution and 30 minutes after induction the measurements were taken by immersing the rat's left leg in a plestimometer until the solution reached the upper limit line of the rat's left foot and the numbers were recorded obtained. Changes in fluid volume were recorded as rat foot volume (Vt). Measurements were taken every 60 minutes for 360 minutes.

\section{Calculation and data analysis}

Data obtained in the form of the volume of rat feet, then used to calculate the inflammation that occurs with the following calculation equation (Adedapo et al., 2014):

$$
\% \text { Inflammation }=\frac{V t-V o}{V o} \times 100 \%
$$

Explanation :

Vt: Mean volume of rat feet after 2\% carrageenan induction

Vo: The average volume of rat feet before being induced by carrageenan $2 \%$

The $\%$ inflammation data obtained is then used to calculate the $\%$ inhibition of edema by comparing it with a negative control at the same hour with the following equation (Adedapo et al., 2014):

$$
\% \text { Edema Inhibition }=\frac{a-b}{a} \times 100 \%
$$

Explanation :

a: \% inflammation negative control (at the same hour)

b: \% inflammation control for each comparison dose (at the same hour)

The $\%$ edema inhibition data obtained were then used to see the percentage of anti-inflammatory potential, by comparing with diclofenac sodium as a positive control with the following calculation equation (Adedapo et al., 2014):

$$
\begin{aligned}
& \% \text { Anti-inflammatory potention }= \\
& \frac{\% \text { edema inhibition average dose }}{\% \text { positive control inhibition rate }} \times 100 \%
\end{aligned}
$$

Observation data were collected and presented in the form of tables, graphs and oneway ANOVA (Analysis of Variance) statistical analysis. The AUC data between the volume of edema against the time was carried out by the Kolmogorov-Smirnov test to determine whether the data were normally distributed or 
not. Levene Statistic test to determine the homogeneity of the variants.

Data that has been normally distributed and homogeneous is followed by one-way analysis of variants (Oneway Difference) with a 95\% confidence level and followed by the LSD (Least Significant Difference) test to determine whether or not there is a significant difference. Data analysis was carried out with the SPSS program.

\section{Results and Discussion}

African leaf simplicia is made by harvesting fresh in Cariu Village, Bogor Regency. African leaf used in this research process have been determined at the Center for Utilization and Innovation of Science and Technology, Indonesian Institute of Sciences (LIPI), Cibinong, Bogor. The results of the determination stated that the plants used in this study were the Asteraceae family of Gymnanthemum amygdalinum.

The number of fresh African leaf used was $11.5 \mathrm{~kg}$. Then done several stages of making simplicia until finally it became a simplicia powder and the yield was $1.386 \mathrm{~kg}$, so that the yield was $15.965 \%$.

The African leaf powder was extracted using the infusion method as much as $200 \mathrm{~g}$ with $2 \mathrm{~L}$ of water as a solvent, so that $660 \mathrm{~mL}$ of liquid extract was obtained and then made into a thick extract, the yield was $10.6 \mathrm{~g}$ so that the extract yield was $5.3 \%$.

\section{Moisture content and ash content of african leaf powder}

The gravimetric method was used to determine the water content of the leaves. The obtained water content of $8.94 \%$ Determination of the ash content of African leaf was carried out by annealing using a furnace, and obtained an ash content of $4.615 \%$.

\section{Phytochemical test results powder african leaf}

Phytochemical test results can be seen in Table 1 and it is found that African leaf powder contains alkaloids, flavonoids, tannins, and saponins.

Table 1. African leaf simplicia phytochemical test results

\begin{tabular}{llc}
\hline Phytochemical Test & Observation result & $+/-$ \\
\hline $\begin{array}{l}\text { Saponin } \\
\text { Tanin }\end{array}$ & Formed foam $4 \mathrm{~cm} \mathrm{20} \mathrm{minutes}$ & + \\
$\mathrm{FeCl}_{3}$ & Greenish blue & + \\
Alkaloid & & + \\
Mayer & White sediment & + \\
Dragendroff & Red & + \\
Bouchardat & Brown & + \\
Flavonoid & Yellow & + \\
\hline
\end{tabular}

\section{In vitro anti-inflammatory activity test} results

Protein denaturation is known to cause inflammation and rheumatoid arthritis. Several anti-inflammatory drugs such as phenylbutazone, indometazine and diclofenac sodium have shown activity in inhibiting temperatureinduced protein denaturation (Phanse et al., 2012). Testing of protein denaturation inhibition activity was carried out using the protein denaturation inhibition test method conducted by (Heendeniya, 2018) by making slight modifications to the procedures and formulas to calculate inhibitory power.

Using a modified method, it is known that the inhibitory power of $50 \%$ denatured protein $\left(\mathrm{IC}_{50}\right)$ from diclofenac sodium is $1041.61 \mathrm{ppm}$ or equivalent to the consumption of $520.80 \mathrm{mg}$ of the active substance diclofenac sodium. The $\mathrm{IC}_{50}$ value is obtained from the linear regression equation (Figure 1.A). 


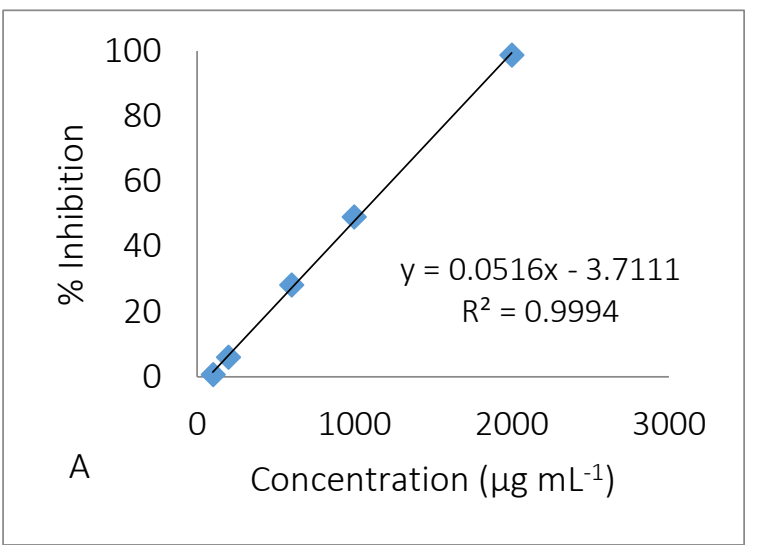

Figure 1. Inhibition of diclofenac sodium (A) and African leaf water extract (B)

The same method was used to test the inhibition of African leaf against 50\% denatured protein. The results showed that African leaf had $50 \%$ protein denaturation $\left(\mathrm{IC}_{50}\right)$ inhibitory activity at the concentration $3751.88 \mathrm{ppm}$ or equivalent to $0.8274 \mathrm{~g}$ African leaf simplicia (Figure 1.B). The inhibition of the protein denaturation process from African leaf extract is caused by the presence of flavonoids (Verma, 2011).

Table 2. Rats' feet volume by treatment according to group at time $t$

\begin{tabular}{clllllll}
\hline Group & \multicolumn{7}{c}{ Volume of foot edema at hour $(\mathrm{mL}) \pm \mathrm{SD}$} \\
& \multicolumn{1}{c}{0} & \multicolumn{1}{c}{1} & \multicolumn{1}{c}{2} & \multicolumn{1}{c}{3} & \multicolumn{1}{c}{4} & \multicolumn{1}{c}{5} \\
\hline I & $0.775 \pm$ & $0.820 \pm$ & $0.850 \pm$ & $0.875 \pm$ & $0.856 \pm$ & $0.841 \pm$ & $0.835 \pm$ \\
& 0.060 & 0.058 & 0.054 & 0.050 & 0.052 & 0.054 & 0.050 \\
\hline II & $0.753 \pm$ & $0.783 \pm$ & $0.805 \pm$ & $0.825 \pm$ & $0.811 \pm$ & $0.798 \pm$ & $0.785 \pm$ \\
& 0.052 & 0.057 & 0.059 & 0.062 & 0.063 & 0.062 & 0.058 \\
\hline III & $0.771 \pm$ & $0.798 \pm$ & $0.826 \pm$ & $0.845 \pm$ & $0.835 \pm$ & $0.820 \pm$ & $0.801 \pm$ \\
& 0.063 & 0.058 & 0.062 & 0.062 & 0.062 & 0.062 & 0.065 \\
\hline IV & $0.758 \pm$ & $0.780 \pm$ & $0.808 \pm$ & $0.830 \pm$ & $0.815 \pm$ & $0.801 \pm$ & $0.786 \pm$ \\
& 0.052 & 0.054 & 0.054 & 0.050 & 0.054 & 0.058 & 0.052 \\
\hline V & $0.760 \pm$ & $0.785 \pm$ & $0.805 \pm$ & $0.828 \pm$ & $0.818 \pm$ & $0.805 \pm$ & $0.786 \pm$ \\
& 0.051 & 0.047 & 0.048 & 0.048 & 0.048 & 0.043 & 0.045 \\
\hline
\end{tabular}

Explanation:

I: Negative control, CMC-Na solution

II: Positive control, diclofenac sodium dose of $5.3 \mathrm{mg} \mathrm{kg}^{-1}$

III: Dose I, a dose $100 \mathrm{mg} \mathrm{kg}_{-1}$ of African leaf water extract

IV: Dose II, a dose $150 \mathrm{mg} \mathrm{kg}^{-1}$ of African leaf water extract

V: Dose IIII, a dose $200 \mathrm{mg} \mathrm{kg}^{-1}$ of African leaf water extract

The increase in edema volume was caused by the release of inflammatory mediators such as prostaglandins, histamine, bradykinin, and serotonin in the tissue after being induced by carrageenan. The decrease in edema volume occurred at 4 to 6 hours. This decrease occurred due to inhibition of prostaglandin synthesis into the tissue. This volume data is then 
used to determine the percentage of edema inhibition.

The percentage of edema inhibition was obtained by comparing the difference between the volume of treatment and negative control. The results of percent inhibition in four treatments, namely positive control, water extract at a dose of $100 \mathrm{mg} \mathrm{kg}^{-1}, 150 \mathrm{mg} \mathrm{kg}^{-1}$ and 200 $\mathrm{mg} \mathrm{kg}^{-1}$ are shown in Table 3.

The analysis showed that the anti-inflammatory effect of the aqueous extracts of African leaves was dose-dependent. The greater the dose of water extract used by African leaves, the inhibition of edema in the rats' feet was also greater.

The results obtained the greatest percentage of inhibition is treatment IV, namely with a dose of $200 \mathrm{mg} \mathrm{kg}^{-1}$ of $38.9394 \%$. This result is close to the percent inhibition of the positive control for diclofenac sodium which is $45.7029 \%$.

Table 3. Percent of edema inhibition according to treatment group at time

\begin{tabular}{cccccccc}
\hline Group & \multicolumn{7}{c}{ Percent Inhibition of average edema (hour) } \\
& 1 & 2 & 3 & 4 & 5 & 6 & $\bar{x}$ \\
\hline I & 44.76 & 39.36 & 40.15 & 45.53 & 46.00 & 58.40 & 45.7029 \\
\hline II & 38.06 & 24.64 & 22.96 & 21.96 & 25.89 & 43.46 & 29.4985 \\
\hline III & 40.59 & 25.19 & 24.58 & 24.35 & 29.62 & 48.46 & 32.1365 \\
\hline IV & 40.85 & 34.73 & 26.55 & 26.69 & 35.27 & 51.95 & 38.9394 \\
\hline
\end{tabular}

Explanation :

I: Positive control, Dosage of diclofenac sodium is $5.3 \mathrm{mg} \mathrm{kg}^{-1}$

II: Dosage I, a dose $100 \mathrm{mg} \mathrm{kg}^{-1}$ of African leaf water extract

III: Dosage II, a dose $150 \mathrm{mg} \mathrm{kg}^{-1}$ of African leaf water extract

IV: Dosage III, a dose $200 \mathrm{mg} \mathrm{kg}^{-1}$ of African leaf water extract

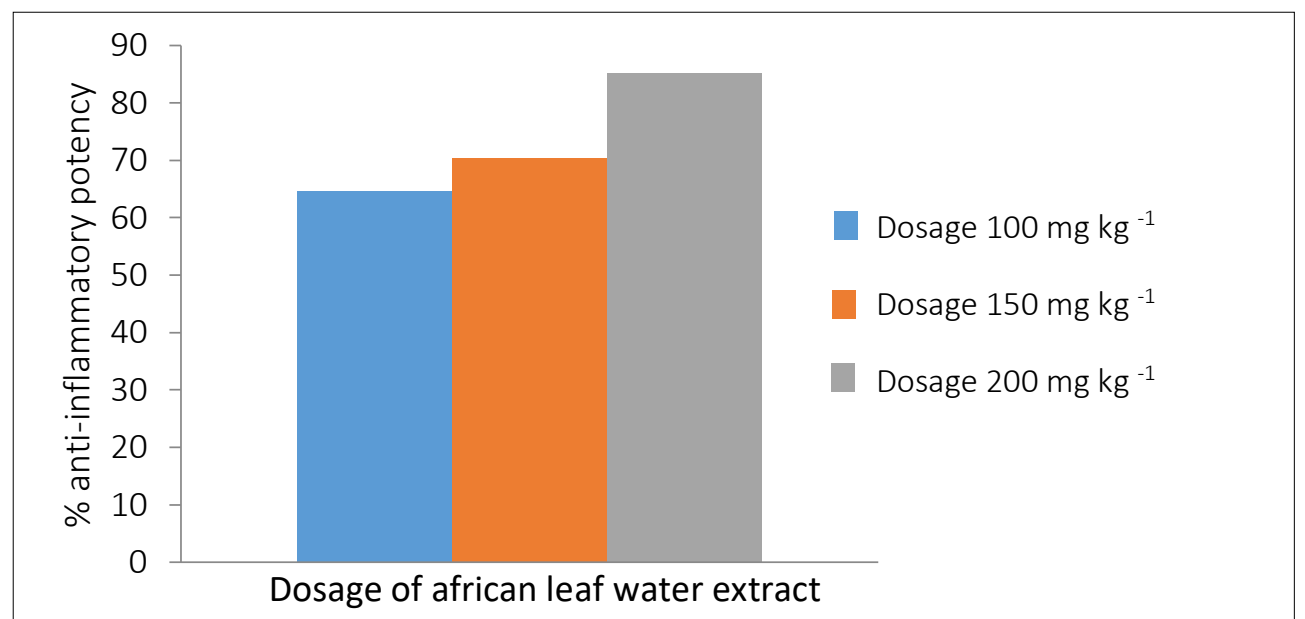

Figure 2. Percentage of african leaf water extract anti-inflammatory potential

The percentage of anti-inflammatory potency was calculated by comparing the percentage inhibition of each dose with the percentage inhibition of diclofenac sodium as a positive control. The results were obtained at a dose of $100 \mathrm{mg} \mathrm{kg}^{-1}$ is $64.54 \%$, a dose of $150 \mathrm{mg} \mathrm{kg}^{-1}$ is $70.31 \%$ and a dose of $200 \mathrm{mg} \mathrm{kg}^{-1}$ is $85.2 \%$ compared with diclofenac sodium as a positive control (Figure 2). So that the water extract treatment group of African leaf which has the potential as the most effective anti-inflammatory is in the $200 \mathrm{mg} \mathrm{kg}^{-1}$ dose group.

\section{Conclusion}

The water extract of African leaf (Gymnanthemum amygdalinum) in the in vitro test with a concentration of $3751.88 \mathrm{ppm}$ was able to inhibit $50 \%$ denatured protein $\left(\mathrm{IC}_{50}\right)$, while in vivo tests has potential as anti-inflammatory 
by the percentage of the most effective inhibitory power at a dose of $200 \mathrm{mg} \mathrm{kg}^{-1}$ which is $85.20 \%$. African leaf have the potential of approximately 2 times greater than the positive control of diclofenac sodium.

\section{Acknowledgment}

This research funded by Deputy for Strengthening Research and Development of teh Ministry of Research and Technology, National Agency for Research and Technology through the 2020 Higher Education Beginner Lecturer Research Grant.

\section{Conflict of Interest}

The authors declare that there are no conflicts of interest.

\section{Authors Contribution}

L.A.S: Conducted field experiments and recorded field observations. L.A.S: Conceived the idea and supervised the experiment and written the concept and discussion. L.A.S and Z.R: written the draft, data analysis and references.

\section{References}

Abdulkhaleq, L. A., Assi, M. A., Abdullah, R., Zamri-Saad, M., Taufiq-Yap, Y. H., \& Hezmee, M. (2018). The crucial roles of inflammatory mediators in inflammation: A review. Veterinary world,11(5), 627-635. doi: 10.14202/vetworld.2018.627-635

Adedapo, A. A., Aremu, O. J., \& Oyagbemi, A. A. (2014). Anti-Oxidant, anti-inflammatory and antinociceptive properties of the acetone leaf extract of Vernonia amygdalina in some laboratory animals. Advanced Pharmaceutical Bulletin, 4(Suppl 2), 591-598. doi: 10.5681/apb.2014.087

Bertholf, R. L. (2014). Proteins and Albumin. Laboratory Medicine, 45(1), e25-e41.

https://doi.org/10.1309/LMKRNRGW5J03APZQ

Drini M. (2017). Peptic Ulcer Disease and Non-Steroidal Anti-Inflammatory Drugs. Australian Prescriber, 40(3), 91-93. https://doi.org/10.18773/austpre$\underline{\text { scr.2017.037 }}$

Farombi, E. O., \& Owoeye, O. (2011). Antioxidative and chemopreventive properties of Vernonia amygdalina and Garcinia biflavonoid. International journal of environmental research and public health, 8(6), 2533-2555.

https://doi.org/10.3390/ijerph8062533

Georgewill, O. A., \& Georgewill, U. O. (2010). Evaluation of the Anti-Inflammatory Activity of Extract of Vernonia amygdalina. Asian Pacific Journal of Tropical Medicine, 3(2), 150-151. https://doi.org/10.1016/S1995-7645(10)60057-0

Hanani, E. (2015). Analisis Fitokimia. Jakarta: EGC, $227-$ 229.

Heendeniya, R., \& Pathirana. (2018) In Vitro Investigation of Anti- Inflammatory Activity and Evaluation of Phytochemical Profile of Syzygium caryophyllatum. Journal of Pharmacognosy and Phytochemistry. 2018; 7(1): 17591763.

Hildebrandt, S., Steinhart, H., \& Paschke, A. (2008). Comparison of Different Extraction Solutions for The Analysis of Allergens in Hen's Egg. Food Chemistry, 108(3), 1088-1093.

https://doi.org/10.1016/i.foodchem.2007.11.051

Ijeh, I. I., \& Ejike C. E. C. C. (2011). Current Perspectives on The Medicinal Potentials of Vernonia amygdalina, Journal of Medicinal Plants Research. 5 (7), 1051-1061.

Nijveldt, R. J., van Nood, E., van Hoorn, D. E., Boelens, P. G., van Norren, K., \& van Leeuwen, P. A. (2012). Flavonoids: A Review of Probable Mechanisms of Action and Potential Applications. The American Journal of Clinical Nutrition, 74(4), 418-425.

https://doi.org/10.1093/ajcn/74.4.418

Phanse, M. A., Patil, M. J., Abbulu, K., Chaudhari, P. D., \& Patel, B. (2012). In vivo and In vitro Screening of Medicinal Plants for Their Anti-Inflammatory Activity: An Overview. Journal of Applied Pharmaceutical Science, 2(7), 19-33. https://doi.org/10.7324/JAPS.2012.2704

Quasie, O., Zhang, Y., Zhang, H., Luo, J., \& Kong, L. (2016). Four new steroid saponins with highly oxidized side chains from the leaves of Vernonia amygdalina. Phytochemistry Letters, 15, 16-20. https://doi.org/10.1016/i.phytol.2015.11.002

Ramadhani, S. A. S. (2013). Aktivitas Antiinflamasi Berbagai Tanaman Diduga Berasal Dari Flavonoid. Farmaka, 4, 1-15. doi: https://doi.org/10.24198/if.v14i2.10816

Verma M. A., Kumar P. A., Kavitha D., \& Anurag K. B. (2011). Anti-Denaturation and Antioxidant Activities of Annona cherimola In Vitro. International Journal of Pharma and Bio Sciences, 2(2):1-6. 